\title{
Ireland, Her Wars and Strategical History
}

\section{Colonel R. A. Shafto Adair Aide-de-Camp to the Queen F.R.S.}

To cite this article: Colonel R. A. Shafto Adair Aide-de-Camp to the Queen F.R.S. (1866) Ireland, Her Wars and Strategical History, Royal United Services Institution. Journal, 10:40, 303-317, DOI: $10.1080 / 03071846609417204$

To link to this article: http://dx.doi.org/10.1080/03071846609417204

\section{曲 Published online: 11 Sep 2009.}

Submit your article to this journal $\pi$

Џ Article views: 3

Q View related articles $\sqsubset$ 


\section{LECTURE。}

Friday, April 13th, 1866.

Gexerat SIR JOIIN F. BUlgGoYNE, Bart., G.C.B.,IR.F., in the Chair.

IRELAND, IUER IVARS AND STRATEGICAL MISTORT.

By Coloncl R. A. Sintro AD.im; F.R.S., Aide-de-Camp to the Queen.

THE subject on which I haro the honour of addressing you, comprises a portion of the history of one of the most remarkable races of Western Europe. The original inlabitants of the land, whose military history I shall endeavour in brief to set before you, form the extreme right of one of those great portions of the human race, which, resting with their left on the eastern shores of the Mediterranean, swept the Greek colonies, and with their main battle stormed the Capitol of Rome. The prominence of this race in warlike pursuits long showed itself by the Atlantic sen. For the early military history of Ireland commenced previous to that which is recorded in the annals of England. Years before the first Norman horseman had crossed St. George's Channel, sarage and terrible wars had raged between the native chiefs and the Danish invaders. The Danes had established settlements throughout that fair land; and in reading the history of these early times, you will constantly be struck with the remarkable derelopment of military and strategical science in the contest between those two great peoples, as given by bard and chronicler.

But my business to-day is with that rell-defined history, which emerges from this twilight, and is recorded in authentic annals. In the consideration of the five or six grent periods of war into which the military history of Ireland divides itself, it will be remarked that campaigns, as well as battles, were mainly determined by topographical circurnstances.

Ireland, topographically is distributed into river systems; and on those river systems to a great extent, depended the origin, formation, and the course of wars. For instance, in the valley of the Barrow and the Siancy, passiing north wards to the Liffey and Boyne, it is 
casily discovered why the strength of tho Norman conquerors was first concentrated within those borders. In tracing the line of the northern lakes from Ballyshannon to Dundalk, it will be perceived wherefore the north constituted a great fortress, from which natire war was waged against intruders on the Irish soil. In the line of the Shannon, passing through a long series of lakes, will be seen the district in which the native chiefs and their followers found refuge when they were unable to stand before the organised system of Norman war. And in the valley of the Blackwater, that great district which is comprehended between the Suir, the right bank of the Barrow, and the Nore, Jou will observe the circumstances that gave facilities to the. Normans to entrench themselres in the defensiro works which are specially adapted to their arms; in the fortified Norman castle.

I have said that the military history of Ireland commences earlier than that which is recorded in the amnals of England. And to any one who has trarersed Ireland with the eye of an antiquary, it must have constantly become crident that the nativo races had the habit of forming carth defences of a regularity and a consistency which have enabled them to remain undestroyed, although degraded in outline, to tho present day. And wherever the mound which is is now called the Danish rath or moat, but which I profer to believe the residence of the early Irish chicftain and his followers, is found on a river a ford almost always is near. The bridges of Ireland are determined by the ford, and the fords are marked by the raths or the moats of that country.

The carly history of Ireland not having commenced with the inroads of the Normans, it is not particularly necessary to dwell here upon that section of her history. Nor, indeed, till the close of the reign of IIfenry VIII, is there very much from which a soldier can gather instruction, except in potrer of endurance and display of gallantry in the fichd. True it is, that some of the great battles that have left an impression upon the popular mind even to this day, were fought in the trrelfth, thirtcenth, and fourteenth centuries. The fights of Knocktuadh, or the Hill of Axes, in Galway, 1189; Credran in Sligo, 1257; and Ardnocher, near MIullingar, 1328, hare a place int Irish legend and story. There was the war of invasion of Edward Bruce, which was waged principally in the north, and successfully. But till the' close of the reign of Ileny VIII, there is rery little on which I need observe.

With the termination of that monarch's life, and the enthronement of his successor, a novel phase of war was developed in Ireland. Europe, at that time, was disturbed in its length and breadth by a conflict, which did not fail to convey its pulsations even to the remote island of the WTestem sea. The wars of Elizabeth which had been waged in the Netherlands against the preponderating weight of the Spanish monarchy, were destined to bo continued and fought out on Irish ground. $\Lambda$ nd there was another cause that lent an intensity to this warfare, resulting from the personal relations which the King of Spain and the Sovereign of England bore to each other.

The carly wars against the Plantagenet kings were simply those which 
the Anglo-Irish, who had retired beyond the pale, waged against their suzcrain, or were at the worst, of feudal dependents. But in the wars of Elizabeth, national feelings were enlisted, and national enmities aroused. At that time also, the native Irish chieftains, having amalgamated their power with the Anglo-Irish descendants of the Normans, were competent to take that share in scientific military struggles, 'for which their previous modes of marfare had not fitted them.

Again, it is to be remarked, that the system of the campaigns in which Elizabeth's generals engaged, was determined rery much by the character of the country. When it became the policy of the Lord Deputy to carry his troops to the northward, it was almost always by continuous expeditions and by displays of strategic talent, some of which were well conceived for the end. When, on the other hand, the strife was with the rebels of ALunster, a country studded with the castles of the Anglo-Norman chicfs, it was then a war either of raids and rapid expeditions, to deprive the eneny of the cattle from which they derived a large proportion of their commissariat; or, of single enterprises in which castles were taken by storm, and, in the Irish phrase, "defaced;" rery much as two centuries before is recorded in Froissart in the wars of Guienne and Normandy.

But at first, it does not seem as if the Anglo-Norman-Irish and their Irish allies carcd particularly to seek for foreign help; for it is not till the year 1567 that the Confederated Irish betake themselres for succour to the Spanish King. One of the greatest of Elizabeth's soldiers was Sir John Perrot, a man of excceding talent in council, and of great resolution in the field. He, with far-secing sagacity, proposed not only a system of bridling the revolted chieftains by castles, bridges, and towns; but also of deriving a rerenue from the country which should defray the cost of the operations of the troops. One of his proposals was to build seren towns, Athlone, Dingle, Coleraine, Liffer, Sligo, Newry, and Mayo. All these points are selccted with great attention to strategical valuc. To fortify the passes of the country with seren castles; on the Blackwatcr of the north, at Ballyshannon, at Belleek, to the eastrard of Ballyshannon, at Castle Martin; in the Qucen's County, at Sallins ; at Kilcomane, in the south country, and at Broadwater in MIunster. He proposed also, for the communications, to build seren bridges : at Coleraine, at Liffer, at Ballyshannon, Dundalk, Fermoy, in the south, at Veale on the Slierelogher, at Kell in Clandeboy, and at Dundalk. It scemed, tleerefore, as if Irish warfare was becoming more difficult to the Crown of England than it had hitherto been. Certain it is that, with the accidents of a stroug country, the mode of equipment, and the commissariat, which was not so highly organised as at the present day, very considerable difficulty might have existed.

For instance, it is well said, that "from the north all wars come." And in reviewing this fronticr to which I havo already directed your attention, from Ballyshannon to Lough Erne, along the system of northern lakes, and thenco to the liils of Armagh, Monaghan, and Lowth, till the sea at Dundalk is reached, but three or four passes exist through which troops can advance into that country. Along a

rOL. $\mathrm{x}$. 
great portion of this frontier, it would be difficult now to pass guns and cavalry where, nevertheless, guns and cavalry were passed when the country was incomparably less suited for a warfare which requires heary armaments and scientific arrangements. To the eastward there were but two passes; from Dundalk round to Newry, and the Moyry pass in the hills of Armagh and Louth. If any of my hearers have gono by railway from Dublin to Belfast, they may possibly remember that shortly after ascending from the plain country at Dundalk, a wild district. of mossy and rocky trable land is penetrated before the hills at a considerable elevation above Newry are passed. There is a pass through which the railway now takes them in some four or fire minutes, which detained Lord M Iountjoy, with tho best of the Quecn's troops for many days during these wars. The advantage to 0'Neill, or the rebel generals of the north, was, that if beaten on the Moyry pass, or the alternative passes leading from Dundalk through Kilkeel and Carlingford to Newry, they then retired on the northern Blackwater, which affords but two points of crossing; at Charlemont, where a ford was built by Mountjoy, and at the ford of Benburl. The alternativo was for the English generals either to be checked at the passes of these hills, or compelled to accopt battle, which was certain to bo offered at Benburb. If the northern troops wero defeated, thero was open to them a safo retreat through the whole of the wooded country to the left of Lough Neagh; and finally, after the fashion of clan warfare, the dispersion of the tribes left no opportunity, thoroughly, to break their strength.

But the generals of Elizabeth wero not without thcir counsel also. Finding the difficulty that arose from this description of warfare, they reversed, as it were, the front of the northern rebels by constructing one fort at Derry and another at Ballyshannon. The consequence, as will be perceived at once, was this : that, after forcing the passes of the Dundalk system, the English troops, in their adrance, were approaching their commissariat instend of retreating from it; and since the command of the sea was always with the English navy, the transport of reinforcements was easy.

Frankly, nothing is more difficult than to select, among numbers of gallant deeds and remarkable achierements, some few as types, signs, and specimens of the warfare of those times. And first, of a most remarkable march made, in 1594, by Sir TVilliam Russell, Lord Deputy.

Enniskillen was besieged. The Lord Deputy resolres to raise the sierc, and passing, on August 19th, from Dublin to Trim, from Trim to Alullingar, Athlone, Roscommon, Abbey Boyle, on the 26th passes the Curlea mountains, thence by Drumlane, over the hills of Killarga and the bogs of Ballynamarla, passes the Erne River on the 30 th with $500 \mathrm{men}$, relieres Ennishillen without stroke of sword, and returns to Dublin on the 9th of September. Then, with regard to Derry, - that Derry was not the Londonderry of the famous siege. It was a small post occupied by the Queen's troops. On one occasion it was necessary to abandon it before the inroad of the northern rebels. The garrison, being principally of infautry, were embarked, but there 
was a troop of horse commanded by one Captain George Harrey, who resolved they would not leare their horses, but that they, with their horses, should pass through tho enemy's country unharmed. This gallant man took no counsel but of his own courage, and marching through a country swarming with enemics, broken and difficult as it then was, he presented himself, at length, at Dublin with his command undiminished by fatigue of way through Tyrconnell and Connaught, or by perils of war. Such deeds should never be forgotten; for whon the toil and peril are realised with which such gallant resolutions are carried into effect, it will be seen how well such men deserve of their country, and a place in English history.

Another peculiarity of the military system of Ireland was the position which the citizens of Dublin occupied in the warfare of the times. The number of expeditions in which they are named, from 1466 to 1598 , in 132 yenrs, is fifteen, in which they deliberntely took the field in support of the Royal power, or on their own behalf. On one occasion the Royal troops not being available for the relief of Dundalk, the town was relieved by the armed citizens of Dublin.

But not always was rictory to the Queen's troops. No; on some occasions there were sad and terrible defeats. The Irish fought well; and they fought with a determination which won for them the respect of their opponents; and no man who has read the account of the famous "Pluck of Plumes," in which the chivalry of Essex were defeated by a body of Irish, but will say that those men were the true ancestors of the gallant Irishmen who have carried the British arms throughout the world.

But the warfare that had been waged against discontented families of the old Anglo-Norman type or the native Chieftains of the North by the Generals of Elizabeth was about to be finally closed in the most distinct and decisive manner on the southern shores of Ireland. Two inconsiderable expeditions, comprising a small number of Spaniards, had bcen landed at Smerrick, on the west, whence, on one occasion, they had penetrated into the country, and had been taken prisoners. On another, they constructed a snall fort, which was besieged by tho Lord Deputy Grey de Wilton, called the Fort Dell'Oro. There one of those terrible tragedies was enacted on which the historian hesitates, the soldier reads, and is silent. The garrison was put to the sword, and for a time there was no further inroad by the.Spaniards. But Spaiu had not forgotten her soldiers. At Kinsale, in 1601, the Spaniards disembarked a large body of forces. An impression had for some time existed that a Spanish invasion was imminent; yet there was but one man, and fortunately he was the man in the right position, who had guarded himself, for the struggle he saw was inevitable. The Lord President of Munster, Sir George Carew, chief of the artillery of England, had for six months previous been providing for the storm, and when it came, he was prepared for it, in that quiet, unobtrusive way in which true soldiers await a difficulty. At the Council table he told the Lord Deputy and the astonished Council that he had already accumulated six months' biscuit by paying his men in money instead of issuing their rations. The Lord Deputy arose and cmbraced him, 
and forthwith placed the confidence in him which the soldier deserves who, with simple expedients, stores up the clements of success.

Kinsalo was besieged. 'The Castles of Bereharen and Castleharen were occupied and formed into works dependent on. Finsale under the Spanish military system. The siege proceeded with varied success; but at length news came to the Lord Deputy that the northern armies with Tyrone were on the march, and that while he maintained the siege he would hare to fight a battle in the ficld. Ho rras equal to the emergency. With one hand he drove back sallies of the garrison of Kinsale; with the other he smote Tyrone to defeat within six miles of the fortress. IIence a collapse of the Spanish efforts to make and maintain their footing in Ireland. The treaty of Kinsale closed a great war; Tyrone's submission followed; and for forty years, with but trilling exceptions, the land had peace.

In the reign of Edward VI. the O'MIores and the O'Connors lost territories which are now called King's County and Queen's County. There was a partial insurrection under Sir Cahir 0'Dogherty at Derry, but effectively there was no warfare to disturb the Imperial repose. But the storm was brewing. In 1611 one general burst of insurrection envelnped the English garrisons and cities in its fury. The Irish of the North, under Sir Phelim O'Neill, swept through the country, so that before Christmas the English hold only Londonderry, Carrickfergus, and Droglieda, in the north; Cork, Youghal, and Kinsale, in the south. Dublin remained the city of the Lord Deputy under the English administration, but beyond the walls of those cities there was no place for a family of English blood. Lord Ormond, in his duty to his sovereign, marched out of Dublin; and the Scottish forces, collected in the north-east, defeated Sir Phelim O'Neill at Newry.

And here I must pause for a moment to remark on a new warlike element that is introduced into Irish history. It was in the thirteenth century that the first inronds were made in the north-castern angle of Ireland by the isles-men of Macdonnel on the district which is called the "Ronte" of Antrim. They seized the linds of the sept of the II'Quillans at Dunlnce, and thence gradually spread orer the country. In the interral between the death of Elizabeth and the outburst of the northern insurrection, the Scottish settlers had become rery numerous, and had introduced themselves as a forcign and intrusive element. Consequently their interests were distinct from those of the natice race. Although they probably might not, in accordance with the Scottish policy, be riell affected to the Linglish Crown, they were nerertheless a popnlation hostile to the Irisli.

While Sir Phelim 0'Neill was battling with the Scottish settlers, another and an independent body arose in the south-west. These were the Roman Catholic confederates of Kilkenny, who formed what was called the army of Leinster. They declared for the King; but, nevertheless, were not disposed to submit to the military government of Lord Ormond. In fact, the northern army under Sir P'helim O'Neill, called the army of Ulster, and the southern army under General Preston, called the army of Leinster, or the Catholic confederated army, combined to hold their ground, first of all, against tho Scots, and 
then to maintain an armed neutrality against Lord Ormond and the army of the King.

But the influence of the Parliamentary party in England was now beginning to make its way in Ireland. The same cause which brought Ormond into the field brought the confederated Catholics and the army of the north-the army of Ulster-into the field against the Parliamentarians and the Scots, who were equally obnoxious to both. But though the resistance directed against what was evidently the parliamentary policy of England was overcome, there was no opportunity afforded to the Parliament for seren years of sending any troops to Ircland to renew that defeated policy. It is a complicated task, and of most conflicting evidence, to trace the different operations of these four distinct armies. The army of Ormond, the army of the Confederates, the army of the North, or Ulster, and the Scottish army, each had its own separate interests. At one period, towards the close of 1617, Lord Ormond appears to have been endenvouring to make terms with the Catholic army and tho Scottish at the same time; and thus the war might have lingered on year after year with but very little change, had not the popular power in England, sliaking off its native opponents in the Royalists of England and Scotland, found time to turn attention to the Irish wars. The first sign that was giren of the altered state in which these wars would be waged was by the appearance of that great soldier, Cromwell, in Dublin. It had been lis intention, originally, to land in IFunster; but his Lieutenant-General, Colonel Jones, having, by most successful strategy defeated Lord Ormond and the Royalists proper, to the northward of Dublin, and in the neighbourhood of Dublin, Cromwell turned thither, and thence began his mighty carcer. In seven of the noblest and clcarest despatches in the English language ho shows how, in nine months, he swept through the country as never conqueror swept before. From Drogheda to Wexford, Ferns, Gorey, Youghal, Waterford, Dungannon, through the whole westward of MIunster, by New Ross and so to Clonmel. 'To shorten the history of his great battles; that clief met with neither check nor defeat, and, from a strategical point of view, it is instructive to mark how he passed on, securing his positions as he adrances, learing unnoticed or masking what can bo left, storming what must be stormed, connecting links of communication; always rictorious, always successful, always just, and always careful for the soldiers who enabled him to, perform such great decds. There is a rock near Maryborough famous in Irish story, whence the line of the South Western Pale can be seen. The greatest castle of the Fitzgernlds can thence be seen -you can mark the circumstances of the ground by which the Western" Pale" was naturally bouhded; and, standing there, I have marrelled how the artillery of those days was transported that breached the fortress which crowned this rock; how the guns were got across the surrounding moss; but wherever he laid his hands the work was thoroughly done, and it was done as described in despatches, which reproduce vividly every detail of action, and described in a spirit which, to my mind, proves the soldier and the statesman. In $\mathbf{1 6 4 9}$ Cromwell quitted Ireland, but it was not till 1652 that the adoption of 
the articles of Kilkenny enabled the Parliament to withdratw their forces from the field. Permission was then given to those who had served against the Parliament of Fngland to transfer their arms to any country with which the Parliament was in amity. 7,000 troops were embarked then for the service of the King of Spain, and 3,000 more in the following year. 5,000 more took service with the King of Poland, 3,500 went to scrro the Prince of Condé in France; and between 1651 and $1654,34,000$, of whom few erer saw their loved natire land again, were passed beyond sea as soldiers into foreign lands.

Such was the first great exodus of the military strength of Ireland. Such was the first occasion on which the soldiers who should hare found an outlet for their valour, and fields for their gallant actions in the service of the British Crown went, alas! beyond the seas, as has been said,-

"To tum the scrie on foreign fields

For forcign monarchs' gain."

It was not the last, as we shall see, when we come to the record of the wars of Britain.

It was to be supposed, as history has shown, that in the course of time the seed that had been sown during the wars of the Commonwealth, both in politics and arms, would bear fruit. So it was in England, and so eventually in Ireland, when the King had left whitehall at the approach of William. It was not probable that he erer thought to wage successful war for his crown in Ireland; for at that time, owing to the diminution of the military caste in Ireland, the genius of the nation was not held very capable of military adrenture. Moreorer, the Ulster plantation orerlaid with a stern and resolute population all that existed of discontent in the divided portion of the south and west of Ireland. But it was soon perceived that there was a lever by which, perhaps, the State might be so moved that the Crown might be regained for the fugitire monarch; and the French King who now strained every effort in war with England, gave the exiled King, liberally and royally, assistance of treasure, arms, and men.

It is remarkable that line also tho two chicfest exponents and champions of opposed systems of policy were again brought face to face, and for a conclusire struggle' on Irish soil. What Philip the Second was to Elizabeth, the French King was to William the Thirdan equal destiny and the same fate awaited both. It was perceired that Ireland must be the field of battle, and a fresh insurrection garo the first signal of strife. Kenmare, Ennishillen, and Londonderry were respectively the scenes of a stout and soldier-like resistance, which gave time to their countrymen to collect their strength in aid, and to England to marshal her powers for their deliverance. Of these two famous sieges but little need be said. All men know with what constancy the defence was maintained, and how from that double base of operations, Enniskillen and Londonderry, the subsequent campaigns may be said to have proceeded. Yet to Kenmaro isolated, and of weak 
resource, no less honour is duc. William was, above all things, a soldier, and the Generals trained under his charge and care-were soldiers of the first capacity. Schomberg arrives in Carrickfergus, and disembarks there with little or no resistance, but perceives that his troops are insufficiently drilled. He retires to winter quarters at Lisburn, occupies Dundalk, and awaits the spring. With the spring came 30,000 soldiers from England, and with them a man whose strategical merits and personal character were not to be weighed by any amount of mere military experience. William the Third finding the troops properly drilled, advanced to the southward, till no barrier but the Boyne lay between the armies, and a battle must evidently be near at hand.

It is noticeable how in war striking incidents repeat themselves. It will be remembered that Moreau lost his life under the concentrated fire of field guns across the Elbe. The same artifice, I will call it, liad becn practised against Williom, at the battle of the Boyne. It is interesting to read the account, as well depicted by our latest historian, of William, while at breakfast, looking at the allied Irish and British troops, being greeted by a.salvo of artillery, which strikes lis shoulder suficiently to draw blood, but not to disable. William's army was composed, in accordance with the parallel I have instituted, of those whom a thirst for freedom of conscience had driven from their homethe French Huguenots; and of those from England who were prepared to maintain the free rule of William's Government. The field of battle is ensily comprehended, since it is comprised almost within the two banks of the river Boyne. On the right of William's position is the bridge of Slane, in the centre lies a ford which can be passed by infantry; and on the left the cavalry were to advance. The bridge of Slanc had been singularly neglected by both generals, and as each perceived his error, he endearoured to seize the important position. The bridge of Slane was occupied by a detachment of Wrilliam's caralry, who' thus turned the left flank of James's forces, and when tho IIuguenot battalions and English infantry adranced through the stream to the attack of the old rord, they fell on an enemy already shaken by a caralry adrance on their left. So the battle of the Boyne was won. The army of James retreated to Limerick; and the result was that Ireland was dirided between the two Kings, pending the final struggle. William's garrisons lay from Castleharen to Mallow, from Mallow to Cashel, from Cashel to the northward to Longford, from Iongford to Cavan, Caran to Enniskillen, thence resting on the western sea. A proportion of neutral territory lay between, but King James's troops had the entire control of the province of Connaught, of both banks of the Shannon, and of a very large portion of Munster.

The first expedition that was made, was to form the siege of Limerick by William, whereat a gallant feat of arms was done by a noble soldier of King Janes. William was bringing up his artillery for the siege. It had reached a point some miles on his right rear. Sarsficld detaches himself from Limerick, makes a detour to his right, surprises the park and convoy, and the first thing that is known of the destruction of the expected park was from the explosion of the bursting guns. Sarsfield 
effected his retreat in safety, and limerick was for the time saved. Yet though it was scarcely to be conceived that the Great Deliverer would leavo his work half accomplished, yet from October, 1690, till May, 1691, nothing was attempted in the field, while preparations were made to close the campaign. Meanwhile Marlborough (his first appearance in our civil wars) had taken Cork and Kinsale. The garrison of Cork had been allowed to retreat to Limerick; the garrison of Kinsale were retained as prisoners.

The army of William broke up from winter quarters and marched to Athlone. Athlone was always held to be the chicf military position of Ireland. On the Sliannon, flanked by morasses, lakes, and currents of that stream, it could only be attacked in front, and thus is of a naturally strong character. At this time the French general, Saint Ruth, had been sent to take charge of the Irish officers. Me supcrseded, to the great regret and discontent of the Irish, their General Sarsficld, a noble soldier, as lias becn shown.

The siege of $A$ thlone began. Situated on the Shanmon, and divided into the Irish and Engish quarters respectively on the right and left banks, the fall of one portion by no means inferred the fall of the unassailed portion. The English quarter was soon breached and carried. Saint Ruth broke down the bridges that connected the Irish quarter-that is to say, on the right bank - with the English quarter. IIo had previously committed a great fault by allowing his garrison of Ballymore, which is in adrance of Athlone, to be surprised. There he lost a thousand men, which dispirited his soldiers; but with that exception lio appears to hare fought cautiously and well. But then arose this difficulty. He left Athlone to be defended by lis Lieutenant-General D'Husson, and limself retired somo distanco to the left rear, under the impression that his presence was not required; and thus the fortunes of $A$ thlone hung upon a thread. It is said in a remarkable work on the defence of Ireland, published in 1795, that a council of war seldom fights; but on this occasion the council of war summoned by $\mathrm{De}$ Ginklg determined to fight. And they fought on this wise: they saw it was impossible, without a wasteful expenditure of men and a great loss of time, to carry by siege the remaining quarter of $A$ thlone. They therefore determined to storm, without brenching, at a ford sonio short distance abore the broken bridge. I believe there is no instance in history of so large a storming party assaulting so strong a place as the forlorn hope of 1,500 grenadiers, who crossed the ford of Athlone, and in ten minutes mado the Irish quarter their own.

Saint Ruth found his mistake when too late. Ile was, howerer, of promptitude equal to any emergency. The next morning it was perceived that his troops were directed in retreat to the country between the Shannon and the Suck, on a point at Aughrim. This is a famous name; famous for a battle fought in a scientific and admirable manner. Saint Ruth retired to a position at which he had on his front a long low line of bog, on his left the old ruined castle of Aughrim, and was posted so that there was no point on which it would appear that troops could approach him except on his right flauk. But he omitted to project on his right front a force sufficient to occupy that pass through 
which the English infantry were enabled to advance to the attack. IIte then brought up caralry from his left for the purpose of outflanking the British infantry in their tun on their advance. That left an openinf to the northward of the bog on his Ieft front, across which the English cavalry struggled, turned his left flank, and enabled the English infantry, which were then moring through the bog up to their waists, to storm his intrenchments and secure the day. Saint Ruth's head was carried off by a cannon shot. IIo liad not given any instructions to Sarsficld, his second in command. Thero wns no one to give any orders, and no one to receive them. The broken army of Athlone fled in disorder; and the only places then capable of opposing: the English were Limerick and Galway. Galway after a time surrendered. 'The investment of Limerick was immediately formed.

It may, perhaps, surprise many to hear that pontoons were used at the sicge of Limerick for passing cavalry over the river. Limerick stands as Athlone, divided by the Shamnon. On the right bank the cavalry of James were encamped. Ginkell throws across the stream a bridge of "tin boats," on which he passed over his cavalry, routs and drives into the interior all the cavalry of King James, recrosses with success, returns and destroys the forts on the mest bank, and finally drives Limerick into capitulation. A capitulation is made by which permission is given to the defeated troops to leare the country and to enter the service of the King of France. Eleven thousand men elect to follow their Irish leaders and serve under the French King, two thousand to return to their. homes, and one thousand to serve under William.

But the contest which had thus been waged to a conclusion between two opposite principles of Government on the Irish soil, did not terminate on these fields. For we find in the inroads into Piedmont by Marshal Gatinat, that, while the Irish battalions fouglit with courage round the standard of the French King, their old opponents, the French Huguenots, again met them under the banner of Saroy, and the fight was maintained with honom to both.

Nothing more remains to be said of the great wars of Ireland. There was a period, howerer, in which the Irish military character was dereloped with a rapidity and efficiency which must strike all who have ever read the records. I allude to the enrolment of the Volunteers, when the Frencl and Spanish flects combined, were riding in the channel. The English Government had told Ireland that no troops were to be spared for her defence. The Irish armed themselves. The history and traditions of that great army show how admirably it was appointed and equipped. The Toluntecrs would have given satisfactory proof, if any enemy had approached, of what the Irish spirit was, in those times, after an interval of eighty ycars of peace unbroken, except by the surprise of Carrickfergus.

There is one trar that still remains to be remarked upon: It was the last of the wars of Ireland; I speak 'of the expeditions that were directed from France by the Republican Government agaiust that country in 1796 and 1798.

The expedition of 1796 was prepared with very great care; and 
was of very considerable weight compared with other cxpeditions of those days. It was composed of seventeen sail of the line, thirteen frigates, two frigates en flutte, five corvettes, 15,000 troops, 41,000 stand of arms, twenty field and nine siege guns. It left Brest on the 1st of December, and returned to Brest with but seren ships of the squadron on the 30th. No impression was made upon the Irish soil; and that magnificent expedition was dispersed by the force of the elements, without a single slot being fired by the British forts or troops.

In 1798 , the attempt was repeated. Ilumbert had been stationed at Rochelle with 1,000 men; IIardy at Brest with 3,000 ; and Kilmain with a reserve of 9,000. Mumbert sails from Rochelle, and disembarks at Killala Bay on the north-west. When I come to speak of the defences of Ireland, I shail remark the special conditions which probably induced hin to land there. But having remained at Killala a week, he advances into the interior; is successful at Castlebar; but his career is checked, before his final defeat at Ballinamuck. And I now read, with great gratification, an historical record from which it may be shown that Ireland can trust in last resources to her own soldiers for her defence. It is an extract from a work by Golonel Blacker:-

"What service militia regiments may render, is strikingly shown in "the history of the capture of the French colours in Humbert's " expedition in 1798, by the Light Company of the Armagh regiment. " CHumbert, after a sojonrn of about three weeks in Castlebar, " ' marched northward. He had reason, and (as it turned out) good " ' reason to expect ho should be joined by powerful reinforcements "6 " on the shores of Donegal; he had, moreover, some desire of " " plundering Sligo by the way, but being met and turned by Colonel "s " Vereker and the city of Limerick regiments at Colooney, he "6 " whecled to his right, crossed the Shannon, and made for the county "6 ' of Longford, where he had reason to expect he would be joined by " " a large body of insurgents. He was met near the lamlet of " 'Ballynamuck by the adranced guard of General Lake's army. On 's ' the 8th of September a part of the French, under General Sarrasin, " " at first surrendered, but afterwards resumed the offensivo; but "s ' the main body with their claracteristic bravery showed fight, and " " General Craddock (afterwards Lord Ilowden) was wounded. This " " led to the adrance of the Light Brigade and Armagh regiment. "6 s The brigade consisted of the light companies of the Monaghan, "s 'Tipperary, Kerry, Dublin City, and Armagh. It moved left in front, "s " which caused the Armagh to lead and come first into contact with " " the French-the Armagh regiment moving parallel to it at a little " ' distance. The French gave way before the sush of the Light " ' Company (under Captain Obre) throwing down their arms, and in "s " the mélée, the colours, now at Gosford Castle, fell into the hands of " ' a prirate named Toole, regimental servant to Licutenant TV. 65 "Dobbs."

Those colours I have seen, and those colours I believe to have been the first wrested by British soldiers from the troops of the French Republic. 
Then, simultaneous with this was the unhappy rising which we call the Rebellion of 1728. Twenty-two combats, skirmislies, and battles distinguished that term. On that point it is not necessary to speak.

Now, with regard to the question as to the future Defences of Ireland, or as to systems that have been adopted. In tho cleverly executed pamphlet on the Defences of Ireland, to which reference has been made, the author is of opinion that the adrance will probably bo made from Galway on Dublin. My impression is, that that is by no means the vulnerable point of Treland. For two reasons. In the first place, tho Shannon, defensible in a higher degree than most rivers of equal breadth, is interposed between Galway and Dublin. In the second, an enemy debouching from Connaught, arrives at a plain country on which regular troops and the regular army would be certainly concentrated, in order to lave the advantage of acting from a centre to a circumference in whatever direction the danger might approach. It appears then, especially with the means that are now given for transporting troops and ensuring accuracy of discmbarcation by steam, that the south-western is the more vulnerable point. It has been matter of public record that the south-western district, the Bay of Bantry, Kenmare, the Bay of Dingle, hare occupied the attention of successive gorernments. In 1807, Sir Arthur Wellesley declared his opinion that Bantry should be made a great naral station. It was fortunate, thougl surprising, that in $\mathbf{1 7 9 6}$ the French Admiral should lay so long in Bantry Bay without having endearoured to disembark his troops, since in the channels of Bereharen thoy were sheltered from any wind, and especially from the east wind, which was blowing with fierceness at the time of his occupation. He was not of course aware of that fact, but it is well known that at Bereharen the anchorage is excellent, and also unprotected. Supposing an advance were intended on the capital, rapidity as well as facility of disembarcation are necessary, especially if with the facility, can be combined a power of concentration. The bays of Bantry, Kenmare, and Dingle, afford that facility of disembarcation and of concentration at a point at some distance in the interior which is required for such operations.

It is probable then that the vulnerable point of Ireland is on these western harbours. And although it may be objected, that it is exposed to the rollers from the south-rest, still wo know that with the power steam gires, that contingency has now ceased to be a formidablo danger. Expedition and concentration are the trro points that are required at present. But, assuming an invasion from the maritime base of the south-western coasts, still the system of rivers, which affected so powerfully the warfare of Ireland in former times, will equally indicato the place of a defensive campaign now. There is, as I venture to suggest for the criticism of those who will honour me by considering my suggestions, a perfectly tenable and admirable lino of defence stretching from Enniskillen down to Cork.

In the first place, there is Galway as a substantial point of defence projected in advance of this line and Galway alone. The line of defence would be traced from Cork, through Mallow to Limerick, thence to Banagher, northward to Athlone, and by Lough Ree 
to Enniskillen. In rear of this lino may bo formed many points of support, from which troops and supplies might bo directed on any portion threatened. And supposing this line cren is passed in the rear, still the famous old line which defended the Pale, from Waterford up to Nfullingar would still threaten the adrancing enemy. With regard to the north-west, where Mumbert found his hopes deceived, that is not very likely to bo again invaded. The shores are difficult and the country is wild, although the population is insufficiently dense to be prepared to resist, so far as a population can resist, a military inroad of an unencumbered enemy. Besides, on their left adrance would be the lines of lakes of Enniskillen and the old frontier of the north, which was always so difficult to force.

It may be assumed then that the line to be observed may be most fitly traced between the mouth of the Shannon and the old IIead of Kinsale. That preparation should be made for eventualities appears to be evident, for I am not one of those who derire from modem history any sound assurance that nations have unlearned war. It secms that in the public policy of Europe there are elements of strife which nay break out, dependent on any accident; and worst of all, elements of strife that may be let loose, not in consequence of a persererance in a settled national policy, or even of dynastic ambition; but dependent on the personal inluence of one or more individuals, on whose frail lives now rests the chance of pence, that we hare done so much and suffered so much to secure, and which we must do much more to secure in order that we may not suffer again.

I could have wished indeed, that a wider opportunity of dereloping the many noticcable incidents of these Irish wars had been given. There has been in each century a school for soldiers as regards early military science; as regards the later let no man suppose that the instruction, which is limited to a small surface, is therefore incomplete. Tactics can be practised, it may be said, almost in a barrack-yard. Certain it is that the celebrated battles and celebrated manœurres which all soldiers study, have not required very large fields for their execution.

There is a map which is intimately connected with the defence of Ireland, to which I will direct your attention. It gires the whole of the bog system of Treland. 'Those brown marks show all the country that is rendered incapable of cultiration at present by bogs, and which very matcrially disturb any tactical operations. This must be recollected also, that reclaimed bog is not hard ground. It is possible to cultivate and give the effect of cultivated ground to bog. But although it is of sufficient consistency to support the roots of cereal grasses, or vegetables, below is that want of density that would, particularly with the artillery of the present day, very soon take the wheels of your guns up to the axle. Finally, Ircland is pervaded by a river system, which enables her generals to determine what shall be her line of defence. Ircland has a sea-coast which has rulnerable points, which enables her generals to determine what the points of attack must be in such or such a case. Ireland has a staff acquainted with every incident of country. Ireland, as I lave shown you, independent of the 
troops of the Crown, has soldiers of her own, who in the rery heat of a fierce rebollion did their duty agninst a forcign enemy, and would do their dnty as well again under similar circumstances.

The Crimraxas: I am sure we all feel it to be rery gratifying to have a gentleman of tho ability of Colonel $\Lambda$ dair derote lis time and attention to the objects of this Institution; and I think $I$ express your wishes in conveying to him $a$ rote of thanks for the very clever dissertation on the many circumstances and events connected with the military listory of Ireland.

\section{APPENDIX. \\ Works of Reference.}

Pacata Iribernia, 1633. 4 history of the Wars in Ireland, during the reign of Quecn Elizabetb.

Desidcrata Curiosa Hibernica, 1772. Compiled from original papers.

IIibcraia Anglicana, 16SO-90. The history of Ireland from the conquest thereof by the English to this present time, with a discourso touching the ancient state of that kingdom, by Richard Cox, Esq., Recorder of Kingsale.

Defence of Ireland, 1795.

History of England, by Lord Macaulay. Cromrrell's Letters and Specches, Carlyle.

Crommellian Settlement of Ireland; John P. Prenàergast, 1865. (A work of great ralue and interest.)

Bereharen IIarbour, a Naral Station and Fortifications, on the South-West Coast. of Ireland, 1866. Lord Charles P. Clinton. 